\title{
PÅ SPORET AF EN MYTES OPRINDELSE
}

Overvejelser over Friedrich Max Müllers oprindelsesteori i lyset af moderne kognitiv lingvistik

Anita Maria Leopold

\author{
Ye Storms, resound the praises of your King! \\ And ye mild Seasons - in a sunny clime, \\ Midway, on some high hill, while Father Time \\ Looks on delighted - meet in festal ring, \\ And loud and long of Winter's triumph sing!
}

Wordsworth

\section{Indledning}

Teorier om religionens oprindelse er et kontroversielt emne inden for religionsvidenskaben. Da jeg indledte mit studie i religionshistorie ved Københavns Universitet for mange år siden, blev vi belært om de fatale fejltrin, det 19. århundredes religionsforskere begik ved netop at søge religionens oprindelse. Nok føler vi en smule ærefrygt for Tylor, Spencer, Frazer, Lang, Marett og ikke mindst Max Müller for at have taget de første skridt til at studere religion videnskabeligt. Men så hører al respekt tilsyneladende også op, for vi står tilbage med en ambivalent følelse, hver gang vi præsenterer disse forskere i forskningshistorien. Dette ambivalente forhold er Tomoko Masuzawa opmærksom på i sin bog In Search of Dreamtime. The Quest for the Origin of Religion (1993). Hun bemærker, at disse teorier om religionens oprindelse blev født i lyset af den kraftfulde viktorianske forestillingsverden som erstatning for manglende konkrete data. Derfor var de ifølge Masuzawa dødfødte, og hvis vi stadig studerer dem, konkluderer hun, så er det udelukkende for at assistere dem med en mere anstændig (og ikke mindst mere sikker) anden begravelse (s. 1).

Det er ikke min hensigt at vække Max Müller fra graven blot for at begrave ham igen. Min interesse for Max Müller skyldes, at der er vakt en ny interesse for oprindelsesteorier inden for kognitionsvidenskaben. Kognitionsvidenskab er, kort fortalt, interesseret $\mathrm{i}$ at kortlægge de grundlæggende neurobiologiske og oftest ubevidste kognitive mekanismer, som danner fundamentet for menneskets sprogevne og abstrakte tænkning. Og ikke ulig Max Müller søger man i dag at afdække, hvilke 'oprindelige' årsagssammenhænge, der ligger til grund for menneskets mental faculty, gennem studier af litteratur, fonetik, grammatik og sågar i visse tilfælde også religion. ${ }^{1}$

\section{Forskningshistoriens syn på Max Müller}

\footnotetext{
${ }^{1}$ Se Sørensen 1997, 31-33 og 125. Podemann Sørensen gør netop opmærksom på lighederne mellem Max Müllers begreb mental faculty og ideer i den nyere kognitionsforskning.
} 
At Friedrich Max Müller (1823-1900) var lidt af en utilpasset ener kan læses både ud fra samtidens kritik og ud fra hans eftermæle. Da Louis Henry Jordan i 1905 skulle beskrive Max Müllers rolle og virke for området Comparative Religion, ${ }^{2}$ udtrykte han tvivl om, hvorvidt hans bidrag bestod $i$, at han lagde grundstenen til denne nye videnskab, eller at hans anstrengelser i virkeligheden bestod i at oprejse en ny, videnskabelig struktur på et fundament, som andre allerede havde lagt (Jordan 1905,150f). Jordans indsigelser mod at give Max Müller hele æren som stifter var, at han aldrig havde skrevet et formelt værk om komparativ religion eller på anden vis gjort meget for at fremme målsætningen for denne nye videnskab. Jordan anså i det store hele Max Müllers livsværk for allerede at være forældet og mangelfuldt (s. 153). Hans indsats, selvom den var prisværdig, led ifølge Jordan under, at han spredte sig over alt for mange områder (s. 154f).

Allerede i 1905, kun fem år efter Max Müllers død, var tiden ikke blot forpasset for de store oprindelsestænkere, men også for filologien som den grundlæggende metode for studiet af religion, som Max Müller havde slået så mange slag for. ${ }^{3}$ Det forklarer naturligvis noget af eftertidens stedmoderlige forhold til Max Müller. Men ifølge Masuzawa afspejler tvetydigheden ved hans eftermæle det faktum, at Max Müller var af tysk afstamning i et anglikansk Oxford, hvor han blev kendt for det, der var hans kæphest - nemlig spekulationer om mytologiens oprindelse og religionens udvikling. Masuzawa tegner billedet af en filolog i skyggen af den engelske etnografiske tradition. Max Müller syntes allerede den gang at have været en sær fremmed person, og sådan er han forblevet indtil i dag (Masuzawa 1993, 8f og 61).

Men måske er det lige netop denne særprægede, og for sin samtid ikke helt placérbare, teori om menneskets tænkning, der bærer ham frem i lyset her ved begyndelsen af det 21. århundrede. Max Müller opbyggede, på baggrund af sine filologiske studier, en egenartet teori om religionens oprindelse, hvor kimen til al religiøs erfaring ligger i menneskets mental faculty, der med en universel mode of action, måske bedst oversat som en særlig form for kognitiv mekanisme, medvirker til dannelsen af såvel sanseopfattelser som tro (1878, 24f). Genstanden for menneskets tidligste sansning af det religiøse er erfaringen af det infinitte:

All we maintain is that the germ or the possibility, the Not-yet of that idea, lies hidden in the earliest sensuous perceptions, and that as reason is evolved from what is finite, so faith is evolved from what, from the very beginning, is infinite in the perception of our senses (s. 32).

\footnotetext{
${ }^{2}$ Helt korrekt var det Science of Religion, som Max Müller arbejdede for. Det er hos Jordan, at dette område bliver til Comparative Religion.

${ }^{3}$ Angående Max Müllers brug af filologien, Müller 1881.
} 
Dermed afveg han fra samtidens darwinistisk inspirerede antropologer som fx Tylor (se Sharpe 1975, 46 og Malefijt 1968, 489) og deres udviklingsteori om religion som en ensartet og lige udviklingslinie fra det, som man anså for det mest primitive udviklingstrin, fetichisme, til troen på højere guder. Ganske ukarakteristisk for sin tid så Max Müller ikke historiens forløb som en organisk fortsat fortælling om oprindelsen og dens udvikling, men som en serie årsagssammenhænge fulde af tab, forfald, fremmedelementers tilfældige sammentræf og afvigende efterspil (Masuzawa 1993, 9). På den anden side afviste han også den almindelige teologiske antagelse om en oprindelig transcendent, guddommelig åbenbaring, for selvom Max Müller forblev en romantisk kristen universalist, delte han evolutionisternes antagelse af, at religion var noget, der kunne studeres rationelt. Sharpe giver et godt signalement af Max Müllers personlighed som sammensat af tendenser i tre af tidens strømninger: tysk romantisk idealisme; komparativ indoeuropæisk filologi og post-hegeliansk historiefilosofi (Sharpe 1975, 36).

Metodologisk set var det filologien, der styrede underkategorierne mytologi og religion, men hans interesse for menneskets religiøse tænkning skal måske findes i de to andre strømninger. Hvor Sharpe ser Max Müllers kompleksitet som et udslag af tre strømme der mødes, tilskriver Masuzawa den hans livs komplekse omstændigheder - at han måtte krydse såvel faglige som nationale grænser (Masuzawa 1993, 8). Gennem hvad hun kalder sit 'arkæologiske' studie af Max Müller, ser hun en anden historie dukke frem bag eftermælet for 'en 19. århundredes lænestols-antropolog'. Det er historien om en mand, der kom til England for at studere og udgive sit værk om Rig Vedaen, men som ikke fik den ønskede Boden Chair of Sanskrit, sandsynligvis fordi han var udlænding - derimod blev Chair of Comparative Philology specielt skabt til ham. Og ifølge Max Müllers hustru, Georgiana Grenfell Max Müller, var det dette skift i professionel identitet, som førte ham fra sprogvidenskaben til videnskaben om tænkningen og religion (Masuzawa 1993, 64f).

Hvis vi godtager Masuzawas fortolkende biografi og 'virkningshistorie’, så ligger formen til Max Müllers teori om religionens oprindelse i hans egen livshistorie. I den forbindelse er det bemærkelsesværdigt, at man her aner et næsten ontologisk skel mellem mytologi og religion, selvom han i sidste ende forsøgte at føre oprindelsen for begge fænomener tilbage til tænkningen. Dette ontologiske skel kan dog bedst forstås som gradueringer af tænkningen, hvor myte er et produkt af sprog og religion et mere direkte produkt af oplevelsen af det infinitte. I det lys bliver Max Müllers teori om religionens oprindelse et kognitivt projekt! Jeg vil i det følgende først overveje hans påstand om myten som the disease of language og dernæst vurdere dens gyldighed i forhold til moderne kognitionsteorier. Til sidst vil jeg forsøge at gøre det samme, hvad angår hans påstand om religion som et svar på oplevelsen af det infinitte.

\section{Sygdommen i sproget}


Max Müllers påstand om ‘disease of language’ er en rigtig ørehænger. For eftertiden har påstanden om sprogets sygdom været at betragte som et underholdende indslag i forskningshistorien, selvom den netop er provokerende ved sin 'common sense'. Og da jeg i et nummer af Weekendavisens kulturtilleg (Frank 1999) læste om “memetikken”, slog det mig, i hvor høj grad denne påstand, i det mindste i metaforisk betydning, stadig er aktuel.

Memetikken er en teori udfærdiget af Oxford-zoologen Richard Dawkins, som har defineret, hvorledes ikke-biologiske kultur-enheder, de såkaldte memer (jf. Blackmore 1999), ${ }^{4}$ i lighed med gener, følger de evolutionære regler gældende for enhver kopierbar enhed. Ifølge Frank beskrev han løseligt

memer som adfærd, ideer, tøjmode eller andre former for kulturelle elementer, der kan spredes ikke-biologisk, når vi direkte imiterer hinanden eller kopierer fra en instruktion. Et meme kan altså udgøres af måden man hilser på sine stammefrænder, firmaets dresscode, en videnskabelig teori, opskriften på coq au vin eller ideen om at genbruge ølflasker. Kort sagt den menneskelige kulturs mangfoldige udtryk (Frank 1999).

Ifølge memetikken spreder kultur sig som en virus, og “den er udelukkende til for sin egen skyld, den er absolut selvisk i sin fremfærd og den snylter på sagesløse hjerner for at reproducere og brede sig” (ibid.).

Måske ville Max Müller, hvis han havde levet i dag, have hilst memetikkens idé om 'kulturel virus' velkommen som en begrundelse for mytens udbredelse, men også som en degenererende effekt, der spredte sig i en bestemt epoke af historien. Men før vi vover os ud i sammenligninger med nye teorier, bør vi først give Max Müllers myteteori den plads, den fortjener. Det har en vis betydning, at Max Müllers mytologiske studier, især studier af indoeuropæisk mytologi og sammenligning af indisk og græsk mytologi, voksede ud af hans komparative studier af indoeuropæiske sprog. Han søgte via sine sammenlignende studier at finde det præ-indoeuropæiske sprog før opdelingen i de senere kulturer og sproggrupper. Han så sig selv som en geolog eller arkæolog, der måtte afdække hvert lag i sproget, som historiens forskellige faser havde tilføjet det, både i form af opgang, brud og degeneration, for at nå tilbage til de ældste formationer af menneskets sprog og tænkning (1881, 23f).

The more we retrace our steps, the more we advance from stratum to stratum, from story to story, the more shall we feel almost dazzled by the daylight that breaks in upon us; the more shall we be struck ... by the marvellous simplicity of the original warp of human speech (s. 40).

\footnotetext{
${ }^{4}$ Anmeldt i dette nummer af Religionsvidenskabeligt Tidsskrift.
} 
Derfra kunne han inddele sproget i forskellige historiske perioder, som hver har båret deres særprægede spor videre under overfladen af de moderne sprog. ${ }^{5}$ Det ældste lag kaldte han den rhematiske periode, som betegner den tid, hvor de mest nødvendige ideer, så som pronominer, præpositioner, talord og de mest simple husholdningsord fandt deres udtryk. Denne periode blev efterfulgt af den dialektiske periode, hvorunder dialekter og nationale formsprog såsom semitisk og indo-arisk blev til (s. 307f). Den tredje periode er den, som Max Müller kaldte den mytopoietiske tid (dvs. den myteskabende periode), hvor sygdommen, ifølge Max Müller, opstod i sproget, og som han fandt var sværest at forstå i forhold til det menneskelige sinds historie, og som han forestillede sig ville ryste vor tro på et gradvist fremskridt for det menneskelige intellekt (ibid.). Max Müller så i den mytopoæiske periode et brud mellem det oprindelige sprogs klare idé om en gradvis formation af grammatik og dialekter, samt dannelsen af de første politiske samfund, religion og poesi - og den efterfølgende for Max Müller så groteske mytiske periode, der fik de ellers så oplyste grækere til at "opfinde absurde eventyr om guder og andre ubeskrivelige væsener” (s. 309). Max Müller erkendte dog, at dette brud mellem tegn og indhold var en del af sprogets begrænsning, og absurditeten i græsk mytologi var derfor en konsekvens af det naturlige sprogs udvikling.

Endelig var det gennem sit studie af Rig Veda på sanskrit, som Max Müller anså for at være det ældste af alle indoeuropæiske sprog $(1878,1310 g$ 152f), at han byggede sin teori om sprogets og religionens udvikling op. I det indiske materiale fandt han en forklaring på den metaforiseringsproces, som langsomt havde fortrængt sprogets oprindelige, direkte henvisende karakter - dvs. at ord henviste til en bestemt form for aktivitet, der fonetisk svarede til den lyd, som man forbandt med aktiviteten (s. 183). Ifølge Max Müller skete denne udvikling, da det gik op for mennesket i den tidlige sprogfase, at der var forskel mellem subjekt og objekt, og at der var forskel på en arbejder og det færdige arbejde:

[The] act which first made man conscious of a difference between subject and object, nay which over and above the perceptions of a worker and the work done, left in his mind the concept of working, as an act, that could be distinguished both from the subject of the act, and from its object or result. This step is the real salto mortale from sound expressive of percepts to sound expressive of concepts, which no one has hitherto been able to explain (s. 185).

\footnotetext{
5 "The formation of language, the composition of roots, the gradual discrimination of meanings, the systematic elaboration of grammatical forms - all this working which we can still see under the surface of our own speech, attests from the very first the presence of a rational mind.” (Müller 1881, 306).
} 
Max Müller så disse primære begreber spire frem under sammenblandingen af lyd og handling, idet lyd blev differentieret ved accenter og andre ydre tegn, så de til sidst kom til at betegne en agent eller et instrument, sted eller tid, eller et handlingsobjekt. Således så han udviklingen af begreber som mere eller mindre samtidige med dannelsen af sprogets grundstamme og dets fonetiske form. Han mente derfor at kunne slutte ud fra disse iagttagelser fra sprogvidenskaben til religionsvidenskaben og til udviklingen af religiøse begreber (s. 186). Samtidig fandt han en forklaring på grundlaget for den mytopoæiske udvikling og den medfølgende sygdom i sproget. Herunder aner jeg antydningen af en metafor-teori:

In the mythological language we must make due allowance for the absence of merely auxiliary words. Every word, whether noun or verb, had still its full original power during the mythopoeic ages. Words were heavy and unwieldy. They said more than they ought to say, and hence much of the strangeness of the mythological language, which we can only understand by watching the natural growth of speech $(1881,369)$.

Det er klart, at vi her først og fremmest kan kritisere lænestolsantropologen Max Müller for, at hans egen uvidenhed, hvad angår andre kulturers betydningssystemer, her skinner igennem. Men hvis vi lægger denne kritik til side et øjeblik, aner vi faktisk en kognitiv hypotese, hvoraf følgende faktorer er gældende: I den vediske litteratur så Max Müller de tidligste spor af et fælles indoeuropæisk arvegods, som han udlagde som beviser for, hvorledes menneskets tænkning har ansporet til begrebsdannelsernes form. Her kunne han iagttage, hvorledes fx floder blev navngivet i overensstemmelse med de egenskaber, man tillagde dem såsom løberen eller larmeren - eller, hvis de løb i en lige linie, så pløjeren eller pilen (Müller 1878, 186). Floder og andre naturfænomener blev tillagt evnen til at handle og blev betragtet som aktører på samme niveau som mennesker. Dermed forstod Max Müller den tidlige begrebsdannelse som et udslag af menneskets hang til at projicere sine egne handlingsvilkår over på omverdenen. Dette anså han for at være oprindelsen til billedsprog:

Here, in the lowest dephts of language, lie the true germs of what we afterwards call figurism, animism, anthropopathism, anthropomorphism. Here we recognise them as necessities, necessities of language and thought, and not as what they appear to be afterwards, free poetical conceptions (s. 187).

Med denne iagttagelse for øje finder vi, for det første, i sprogets natur lige fra begyndelsen, en tendens til metaforisk overførelse og overdetermination. For det andet forklarer det, hvorfor ordenes oprindelige betydning så at sige glider væk eller glemmes og erstattes af nye betydninger, som så efterfølges af et brud mellem tegn og betydning (Masuzawa 1993, 71). Iagttagelsen af denne mytologiserende sygdom i sproget var først og fremmest en iagttagelse af sprogets naturlige og fortløbende betydningsmæssige skred i udvekslingen af begreber (Müller 1881, f), samt det fonetiske 'forfald' (s. 43f), som tømmer ordene for sine oprindelige betydninger og giver plads til nye associationer 
(Masuzawa 1993, 72). Set ud fra mit synspunkt, overrasker Max Müller ved at fremkomme med en ganske moderne teori om sprogets kognitive grundvilkår.

\section{Max Müller og den moderne kognitionsvidenskab}

Lad os derfor vende blikket mod den moderne kognitionsvidenskab for at finde paralleller til Max Müller. Jeg har i den forbindelse hentet mine eksempler fra den del af kognitionsvidenskaben, som jeg vil betegne som den mere lingvistisk orienterede herunder især Mark Turner (1996), samt artikler af Mark Turner \& Gilles Fauconnier (1998, 1996) og George Lakoff \& Mark Johnson (1999). Lad mig dog først påpege, at jeg er klar over, at der er markante forskelle mellem Max Müller og den moderne kognitionsvidenskab. Nogle af de mere påtrængende forskelle vil blive berørt. Men min hensigt er først og fremmest, som jeg indledningsvist antydede, at gøre op med den udbredte og ikke altid lige retfærdige myte om Max Müller og gøre opmærksom på, at flere elementer i hans teori også optager kognitionsvidenskaben i dag.

Det er først og fremmest Lakoff og Johnsons forståelse af, hvad de betegner som primcere metaforer, der udgør en vis analogi til Max Müllers erkendelse af metaforens begrebsmæssige grundlæggelse i menneskets handlingsvilkår. Ifølge Lakoff og Johnson er disse primære metaforer baseret på erfaringer af vor kropslige natur, idet kropslige bevægelser indgår i vore sproglige udsagn som abstrakte handlingsaspekter, dvs. vore kropslige erfaringer er medvirkende til både at forme præpositioner, verber og ikke mindst metaforer (Lakoff \& Johnson 1999, 41f). De primære metaforer afspejler ligeledes et præsprogligt stadie i barnets kognitive indlæringsproces, hvor dets affektive erfaringer blandes med dets sensorisk-motoriske erfaringer. Ifølge Lakoff og Johnson er det her, at barnets subjektive erfaring af kærlighed typisk forbindes med den sanselige erfaring af fx varme - dvs. varmen ved at blive holdt. Som følge deraf formes der ubevidst en slags krydsdomcene-association, hvori der kognitivt set er sket en sammensmeltning af de to domæner, der på et senere trin i barnets udvikling igen differentieres ud, men giver sig tilkende på det sproglige niveau - derved, at vi fx taler om 'et varmt smil’ og ‘en nær ven’ (Lakoff \& Johnson 1999, 46). Hvor Max Müller fandt årsagen til de primære metaforer i menneskets sproglige urtid med dets erkendelse af adskillelse af objekt og subjekt og deraf følgende begrebsdannende sammensmeltning af lyd og handling, finder Lakoff og Johnson årsagen i barnets kognitive og præsproglige indlæringsfase. I begge tilfælde er der tale om kognitive oprindelsesteorier, men i den moderne kognitionsteori er oprindelsen til menneskets begrebsdannelser flyttet fra urtidsmennesket over i barnets universelle og kropsbaserede indlæringsfase. ${ }^{6}$ På den baggrund har Lakoff og Johnson udarbejdet en teori om forskellige ‘årsagslogikker’, der afviser, at begreber om årsagssammenhænge og hændelsesforløb kun afspejler det, der

\footnotetext{
${ }^{6}$ Lakoff \& Johnson 1999, 46: "Each primary metaphor has a minimal structure and arises naturally, automatically, and unconsciously through everyday experience by means of conflation, during which crossdomain associations are formed."
} 
sker i verden uafhængig af tænkningens struktur. Snarere er disse begrebsdannelser fundamentalt set opstået ud fra den menneskelige biologi, og de er udtryk for et sæt af grundlæggende metaforer, der danner strukturen for et hændelsesforløb (s. 171). De forskellige årsagslogikker er ikke blot produkter af en enkelt årsags eller virknings logik forbundet til en enkelt forandrings logik. Fordi der er så mange forskellige former for forandringsprocesser, og fordi der er så mange former for virkninger, hvorved de kan fremkomme, så har vi også et stort antal metaforer, der betegner årsag og forandring (s. 206). En af disse årsagslogikker har naturen som agent for årsagssammenhænge og essens:

The 'Natural Phenomena Are Human Agents' metaphor leads us to a notion of natural causes as forces exerted through human agency. The idea that essences exist as natural phenomena leads to the conception of essences as causes. Essences that have traditionally been conceptualized in philosophy as material or formal, and so the ancient Greek view of material and formal causes is a consequence of a common metaphor for causation that has been with us since before the ancient Greeks, namely, that Natural Phenomena Are Human Agents. The Greek gods were personifications of this metaphor. (s. 225)

Sætninger så som ‘vinden blæste døren op’ eller ‘bølgerne knuste båden’ betegner en generel type af metaforer, som overfører et menneskeligt handlingsparadigme på naturfænomener. Fx opfatter vi døden som en udøvende agent, der er årsag til den enkeltes død, og der kan sågar ske en personificering af døden, som vi kender det fra 'manden med leen’ (s. 112 og Turner 1996, 76). Det er her, vi tydeligst ser analogien til Max Müller.

Hvis vi endvidere skal forsøge at hente en forklaring på den 'overdeterminerede' metaforiseringsproces, Max Müller så som årsagen til den mytopoæiske periodes 'vanvid' (Müller 1881, 309), kan vi fx hente den fra Turners og Fauconniers teori om conceptual blendings (begrebsmæssige blandinger) og blended spaces (blandede rum). Ifølge denne teori opererer den menneskelige tænkning ud fra mange forskellige mental spaces (mentale rum), der kan forstås som 'små begrebsmæssige pakker’, som vi så at sige konstruerer 'her og nu’, idet vi tænker eller taler ud fra en bestemt situation eller handling (Fauconnier \& Turner 1996, 113; Turner 1996, 57). Derved kan der opstå et særligt 'blandet rum', som nok låner en delvis struktur fra de forskellige input spaces (tilførte rum), men hvorfra der opstår en tredje ny og egenartet struktur, som fx når floden personificeres og tilkendes et eget 'mentalt rum' som løberen i Max Müllers ovennævnte eksempel. Vi betjener os således hele tiden af 'små fortællinger', som vi projicerer over i vor sprogbrug, i litteraturen og i det hele taget i de erfaringer, som vi gør i livet - der kan betegnes som en langt større abstrakt fortælling. Denne måde at tænke og beskrive vor verden på betegner Turner som parabolisk, idet han definerer parablen som selve fortællingens projektion, der refererer til et generelt og uundværligt 
instrument for tanken, og som viser sig overalt - lige fra at fortælle, hvad klokken er og til at læse Proust (Turner 1996, 7). ${ }^{7}$

Da Max Müller diagnosticerede myten som sprogets sygdom, anede han, i hvor høj grad vore erkendelser af livet er styret af fortællinger og ikke mindst i hvor høj grad, virkeligheden lader sig skjule i deres konstruktioner og projektioner. Men i modsætning til Turner så han det mytiske sprogs overdetermination som udtryk for sprogets begrænsning i ikke at kunne beskrive virkeligheden, som den virkelig er:

As long as people thought in language, it was simply impossible to speak of morning or evening, of spring and winter, without giving to these conceptions something of an individual, active, sexual, and, at last, personal character (Müller 1881, 360). ${ }^{8}$

Selvom han opfattede den mytiske og tidlige poetiske sprogbrug som en forhindring for tankens erkendelse af virkeligheden, havde han dog øje for, at disse sproglige 'blendings' skabte nye mentale rum og forvandlede naturen til Natura, et enkelt adjektiv som blev til et substantiv" (s. 361) eller, som det var hans pointe med hensyn til sin myteteori, at nomina blev til numina (Masuzawa 1993, 74). Og vist var han præget af sin tids søgning efter oprindelsen (i bestemt form), og vist var det hans intention som en anden arkæolog, at udgrave lagene af 'mytemer' for at finde oprindelsen til tankens åndelige inspiration, som for ham var naturen (s. 74f). Men Max Müller så naturen som den oprindelige inspiration for tankens åndelige fremspring, og han søgte i lighed med den moderne kognitionsforskning at forklare tænkningens vilkår og sprogets struktur ud fra menneskets biologiske natur. ${ }^{9}$ Dermed ligner deres teoretiske udgangspunkter hinanden på trods af, at et århundrede adskiller dem, ved at søge årsager til tænkningen i biologiske og sproglige begrænsninger fremfor i såvel sociale som kulturelle begrænsninger.

Det er også i den sammenhæng, at vi ifølge Turner skal forstå kognitionens paraboliske natur. Han beskriver bl.a., hvorledes vi identificerer objekter som værende 'selv-bevægende' på baggrund af vore kropslige erfaring af at være selv-bevægende individer. Og det er således i vor egenskab som selv-bevægere, at vi overfører 'små rumlige fortællinger, ${ }^{10}$ om vor egen handlingsstruktur på objekter uden for os selv, der

\footnotetext{
${ }^{7}$ Turner 1996, 7:”Parable is the projection of story ... I use the word parable in this unconventional way to draw attention to a misconception I hope to correct, that the everyday mind has little to do with literature."

${ }^{8}$ Se også Turner 1996, 76: "Personification is perhaps the most thoroughly analyzed consequence of blended space. If we revisit the various personifications we have considered - of the wind as a torturer, Death as Thanatos ...”

${ }^{9}$ Se Turner 1996, 159: “The learning of a language may quite literally change the neurobiology of the infant in ways that are influential over cognition. This creates the intriguing possibility that speech and writing could be ways of the brain of one person to exert biological influence upon the brain of another person: thinking may be affected abidingly by experience with language."

${ }^{10}$ Turner henviser m.h.t. sin forståelse af spatial stories til Clifford Geertz og dennes afvisning af, at mennesket opererer med en generel fortclling - snarere er der tale om, at såkaldte generelle fortællinger opererer på et langt mere abstrakt plan, idet de består af flere sammenflettede små historier: "His [Geertz]
} 
synes at have en lignende selv-bevægende egenskab. Det resulterer i, at vi i kraft af denne evne til at blande fortællinger fra forskellige forestillingsmæssige rum kan projicere vore roller som aktører og animatorer over på andre objekter uden for os selv. Dette har ifølge Turner historisk set resulteret i bl.a. begrebet sjeel, som netop er et sådant 'blandet rum', der har fået en egen handlingsstruktur som følge af en parabolisk projektion af 'en aktørs evne til at bevæge et fysisk objekt' (Turner 1996, 21). Den bagvedliggende logik er, at hvis vi antager, at vi kan bevæge en genstand i kraft af vore kroppe, så må de også være genstand for en bevæger. Dvs. at sjælebegrebet fremkommer ved, at man gør kroppen til genstanden og overfører evnen som aktør på sjælen (s. 21 og 76).

Men selvom vi kan se en vis strukturlighed mellem Turners blended spaces og Max Müllers iagttagelse af sprogets personificerende natur, så skaber et helt århundrede dog markante forskelle mellem Max Müllers indledningsvise kognitionsteori og den moderne kognitionsvidenskab. Hvad angår Turner, og især Lakoff og Johnsons 'kropsfilosofi', så tager de udgangspunkt i, hvad de betegner som 'en rationel darwinisme', dvs. at tænkningen, selv i dens mest abstrakte form, er baseret på vor dyrenatur, snarere end på en transcendent bevidsthed i form af en særlig mental faculty adskilt fra kroppen i en mere cartesiansk forståelse af tænkningens natur (Lakoff \& Johnson 1999, 4f og 410f). Det markerer en fundamental forskel til Max Müllers menneskesyn, ${ }^{11}$ idet han dybest set opfattede menneskets rationelle evne som noget guddommeligt givet. Derfor var det vigtigt for ham at opretholde et skel mellem mytens oprindelse som et resultat af sproget(s begrænsning) på den ene side, og religionens oprindelse afledt af menneskets erkendelse af det infinitte på den anden side. I det følgende vil jeg forsøge at gøre rede for det infinittes immanente religiøse betydning hos Max Müller.

\section{Det infinitte og menneskets mentale evne for det religiøse}

Med hensyn til definitionen af religion ønskede Max Müller at få afklaret, hvilke specifikke karakteristika, der kunne siges at adskille de genstande, der har med den religiøse bevidsthed at gøre, fra de genstande, som vi kan forstå med vore almindelige sanser og fornuft (1878, 21f). Max Müller mente, at mennesket måtte være udstyret med en særlig mental faculty for religiøs sansning og tænkning. I modsætning til mytologien så han den religiøse bevidsthed som noget, der direkte er forbundet med sansningen og $\mathrm{i}$ den forstand uafhængig af det sproglige, dvs. den evne vi har til at tro og genkende religiøse genstande med. Dog understregede han, at den religiøse bevidsthed ikke er adskilt fra den almindelige bevidsthed. Det han søgte var årsagen til, at mennesket kognitivt set er udrustet til religiøs tænkning. Men det er dog ikke helt let at

description of the absence of a general story begins with small spatial stories and projects them parabolically onto stories of human thought. Its compelling use of story, projection, and parable demonstrates the general story of the human condition - a story whose existence it denies.” (s. 15).

${ }^{11}$ For Max Müller betød det alt at understrege menneskets rationelle overlegenhed i forhold til dyreverdenen. Derfor var hans menneskesyn i bund og grund anti-evolutionært, idet han på det kraftigste afviste ideen om, at 'menneskeheden langsomt skulle være opstået fra dybet af en dyrisk brutalitet' (jf. 1881, 306). 
gennemskue, hvorvidt han fandt årsagen hertil i denne mental faculty eller i genstanden, det infinitte, som han udpegede som det fænomen, der til alle tider havde været genstand for menneskets religiøse tænkning:

Religion is a mental faculty which, independent of, nay, in spite of sense and reason, enables man to apprehend the infinite under different names and under varying disguises. Without that faculty, no religion, not even the lowest worship of idols and fetishes, would be possible; and if we will but listen attentively, we can hear in all religions a groaning of the spirit, a struggle to conceive the inconceivable to utter the unutterable, a longing after the Infinite, a love of God. (s. 23).

Her er det romantikeren Max Müller, der taler. Og man fornemmer bag ved disse ord en universel, ja, næsten religiøs, forklaring på religion. Det er dog uklart, hvorvidt han opfattede det religiøse som noget, der på én gang er immanent til stede i menneskets mentale evne og i selve fænomenet, det infinitte. ${ }^{12}$ Ifølge Masuzawa anså Max Müller religion for at være en transhistorisk og transkulturel universel menneskelig tilbøjelighed. Religion adskiller sig netop fra mytologi ved at være ufordærvelig, selvom den fremstår i mange forklædninger og ind imellem er blevet usynliggjort af de mange kulturelle og historiske processer (Masuzawa 1993, 67). ${ }^{13}$

Der ligger et næsten ontologisk skel mellem Max Müllers definition af religion og af mytologi. Tydeligvis er religionen i hans øjne naturligt forbundet med sansningen og psyken og derfor i mindre grad udsat for historiens omskiftelighed. Og skal vi forsøge at konkludere ud fra hans tankegang, må religionen ontologisk set være tættere på både vor biologiske natur og den omkringliggende natur, idet den er forbundet med vor sansede bevidsthed om naturen. Mytologien derimod er et skridt fjernere fra vor biologiske natur, idet den som et produkt af sprog og kultur i højere grad er betinget af evolutionens og historiens omskiftelighed. Max Müller forklarede begrebet mental faculty som en særlig disposition i mennesket, der ikke i sig selv kan reduceres til troen på guder, ånder eller andre former for magter. Snarere betegner den en slags naturlov i lighed med tyngdekraften, der bevirkede, at mennesket kunne opfatte, danne begreber og tro - det sidste i form af det infinitte (Müller 1878, 24f). Med henvisning til denne

\footnotetext{
${ }^{12}$ Det er måske her, at man fornemmer en indisk indflydelse på Max Müllers tænkning. Forholdet mellem menneskets mentale evne og det infinitte minder om en slags atman-brahman-tænkning.

${ }^{13}$ Det var også en af grundene til, at han på det kraftigste afviste sin tids kristne antagelse, at klassiske myter blot er fordærvede misfortolkninger af den oprindelige bibelske og proto-kristne åbenbaring (jf. Masuzawa 1993, 67).
} 
facultas occulta, som han også kaldte den, defineres religion som noget kognitivt betinget i lighed med fornuften (reason). Blot er der tale om, at evnen til at ræsonnere ud fra fornuften og evnen eller potentialet til at tro, på forskellig vis aktiveres ud fra det samme sanseapparat (s. 26f). Max Müller anså derved menneskets erkendelse af det infinitte som det, der har aktiveret menneskets potentielle evne til tro i modsætning til det finitte, der snarere er baseret på vor direkte sansede viden (s. 28).

Med termen 'infinit' forsøgte Max Müller at definere religionens objekt, og dermed samle alle religiøse karakteristika til et objektivt og generaliserende begreb. På den måde tog han afstand fra samtidens kritik af religion som udefinerbar og transcenderende den almindelige fornuft (s. 30-32). Og han mente historisk set at kunne følge den religiøse tænknings udvikling gennem en eftersøgning af det infinitte, som han fandt $\mathrm{i}$ den religiøse symbolik fra de tidligste vedatekster frem til nutidens store religioner. Derigennem søgte Max Müller at bevisliggøre religionens objekt som andet end et produkt af menneskets spekulationer - men som en universel sanselig erfaring: ${ }^{14}$

I answer, without any fear of contradiction, that it is his [the primitive savage] senses which give him the first impression of infinite things ... Everything of which his senses cannot perceive a limit, is to a primitive savage, or to any man in an early stage of intellectual activity, unlimited or infinite (s. 37).

Ser man bort fra Max Müllers temmelig spekulative hypotese angående det infinitte, er hans insisteren på en indsigt i menneskets sansemæssige og begrebsmæssige grundvilkår som en vej til at forstå religiøs tænkning ikke uinteressant i lyset af den moderne kognitionsforskning. “Theology begins with anthropology” (s. 38) - et af de mange slagord, som illustrerer hans overbevisning om at have fundet kimen til religion i det menneskelige sind.

\section{Moderne kognitive oprindelsesteser}

Hverken Turner, Fauconnier eller Lakoff og Johnson interesserer sig for religionens oprindelse. I det hele taget har religion hos dem ikke nogen særskilt plads fremfor andre abstrakte, filosofiske og metafysiske systemer. Deres interesse ligger først og fremmest $\mathrm{i}$ at finde de grundlæggende biologiske og kognitive byggesten for sprog, grammatik,

\footnotetext{
${ }^{14}$ Deri minder hans projekt om den senere Eliade og dennes homo religiosus, idet også Eliade søgte at definere religiøs erfaring som mere eller mindre universel - og 'det hellige' som en struktur i menneskets bevidsthed.
} 
abstrakt tænkning og begrebsdannelser i det hele taget. Men i lighed med Max Müller søger de oprindelser. Oprindelsesobjektet er blot flyttet, som fx hos Lakoff og Johnson, der beskriver en 'kropsbaseret realisme' (embodied realism), som grundstenen for vore ontologiske erkendelser af verden (Lakoff \& Johnson 1999, 232f). Eller som Turner, der ser tænkningens paraboliske struktur som kimen til sprog og grammatik. Og det 19. århundredes spekulationer over fortidsmennesket ligger snublende nær i Turners lille opbyggelige fortælling om grammatikkens oprindelse i et urtidssamfund:

\begin{abstract}
Now imagine a community of people who use parable to create rudimentary grammatical structure for vocal sound. Everyone in this community develops story and projection, has a voice, receives training from his parents, and is assimilated into the work of creating grammar through parable. Suppose that into this community a special infant is born with just a little genetic structure that helps it project story onto voice ... If the community is structured so that greater facility with grammar confers reproductive advantage, then the community provides an environment of evolutionary adaptiveness for the genetic change: the "grammar" trait is adaptive ... But grammar itself arose without genetic instruction for grammar. It arose by parable. (Turner 1996, 142).
\end{abstract}

Turners fortælling om urtidssamfundet er et forsøg på at beskrive, hvad han anser som mulige fælles principper og interaktion mellem en biologisk betinget evolution på den ene side, og en kulturbetinget evolution på den anden side, dvs. et forsøg på at finde en sammenhæng mellem den naturlige og kulturlige udvikling (s. 160). Dette er i grunden ikke så langt fra Max Müllers forsøg på at forbinde de historiske processer, hvad angår både sprog, mytologi og religion, til nogle erkendelsesmæssige mekanismer.

7. Man kender ikke en ting, hvis ikke man kender dens begyndelse Dybt forankret i Max Müllers og hans samtids søgen efter oprindelsen ligger der en mere generel forestilling om, at "man kender ikke en ting, hvis ikke man kender dens begyndelse” (Müller 1878, 220). Dette kendetegner ikke blot 1800-tallets darwinisme, men er også, hvad vi ville betegne som en typisk religiøs tankegang. Ifølge Tomoko Masuzawa er der en grundlæggende diskrepans i den vesterlandske videnskabstradition og dennes dom over 1800-tallets oprindelsesteorier, der bærer på nogle af kulturens egne religiøse undertoner:

It seems uncertain if someone in this far end of the twentieth century would spontaneously think of launching on such a quest for an origin ... a number of compelling reasons not to do so have been frequently presented to the students of religion, and many of these reasons are surely deserving of attention. But what is even more noteworthy is the voice, the gesture, the pathos of this prohibition itself. There is at once a humble pride and a special poignancy in this self-denial, or renunciation, on the part of the latter-day representative of "Western man"; in some other circumstances one might be tempted to call such a demeanor "religious.” (Masuzawa 1993, 3). 
Masuzawa påpeger, at i modsætning til videnskab er det tilladt for religioner at have oprindelsesteorier, men dermed ligger der et ambivalent forhold mellem religionsvidenskabens selvforncegtende interesse i oprindelser på den ene side, og forskningsobjektet, religionerne, på den anden side. Derfor kritiserer hun religionsforskere, i lighed med fx Eliade, for blot at flytte interessefeltet og gøre oprindelser til udelukkende et religiøst fænomen. ${ }^{15}$ Ifølge Masuzawa er vor vesterlandske kulturs historiesyn og selvforståelse så forankret i begrebet oprindelse, at den ikke blot dominerer religionsstudierne, men vor videnskabelige diskursive praksis på mange andre felter. Måske bør vi derfor underkaste selve fænomenet oprindelse i videnskaben en nærmere undersøgelse (s. 4).

Jeg finder det berettiget, at vi i stedet for at afskrive oprindelsesproblematikken som noget fortidigt, inddrager den i vore kritiske overvejelser - også i forhold til de seneste neodarwinistiske tendenser, som breder sig inden for både antropologien (jf. Naylor 1996, 37-60), biologien, kognitionsvidenskaben og i sidste ende også religionsvidenskaben. Måske er Masuzawas kritik berettiget, og vi må indse vort ambivalente forhold til fcenomenet oprindelse. Eller forholder det sig ubevidst, sådan som Max Müller så det, 'at man ikke kender en ting, før man kender dens begyndelse'? Er det den grundtanke (i lighed med lægens diagnosticering af sygdomsårsager), som styrer vort videnskabssyn? Måske - men, at det kun skulle være et vesterlandsk fænomen, deri er jeg uenig med Masuzawa.

Jeg tør vove den påstand, at begreber som oprindelse eller begyndelse snarere svarer til en type af klassifikationer, som mennesker universelt set benytter sig af som orienteringspunkter eller årsagsforklaringer. Det gør ikke fænomenet i videnskaben mindre komplekst, men dog mere interessant. Og jeg vil gå et skridt længere end Masuzawa, for så vidt som jeg vil hævde, at vi ikke blot bør gøre begrebet oprindelse til omdrejningspunkt for kritisk selvransagelse af det vesterlandske historiesyn, men i lige så høj grad bør overveje begrebets betydning som et universelt og muligvis i bund og grund kognitivt fænomen.

\section{Konklusion}

Denne artikel skal ses som en undersøgelse af, hvorvidt det kunne passe, at der eksisterer en række ligheder mellem Max Müller og den moderne kognitionsvidenskab. Dette

\footnotetext{
15 "If this prevailing depiction of religion and religious peoples as origin oriented or origin obsessed is brought to bear upon the equally conspicuous matter of scholarly renunciation of origin quests mentioned earlier, this conjunction offers an interesting analytic situation. ... The opposition of renunciation versus gratification thus sharply demarcates and separates the modern scholar of religion from the primitive practitioner of religion, the studying subject from the studied object.” (Masuzawa 1993, 4).
} 
er blevet delvist bekræftet, idet det er den menneskelige tænknings grundvilkår, som er det centrale forskningsobjekt i begge tilfælde. Både Max Müller og de nævnte kognitionsforskere fastholder, at tænkningens struktur er afhængig af menneskets biologiske natur, lige såvel som sprog, grammatik, fiktion, myte og religion bærer præg af menneskets sanseindtryk af omverdenen. I begge tilfælde nedtones eller udelades etnografiske eller socio-kulturelle studier om betydning og religion. Det er således menneskets biologiske grundvilkår, der som årsagsforklaringer får en fremtrædende plads. Men Max Müller adskiller sig ved i en eller anden forstand at gøre det guddommelige immanent i det biologiske og religion til noget, der ontologisk set adskiller sig fra myte. Derved afsløres på markant vis de mere end hundrede år, der adskiller Max Müller fra Turner, Fauconnier, Lakoff og Johnson.

Desuden har jeg forsøgt at sætte fokus på oprindelsesteorier i videnskaben i forhold til Masuzawas kritik af vesterlandsk videnskab og historiesyn, såvel som i forhold til det 19. århundredes darwinisme og vor tids neodarwinisme, der også præger de kognitionforskere, som her er nævnt. Konklusionen er, at oprindelsesteorier langt fra er døde, de har blot flyttet sig fra fænomenet religion til fænomenet kognition. Dog adskiller de moderne oprindelsesteoretikere sig fra Max Müller og andre af datidens forskere ved ikke at søge enkeltstående årsager eller sandheder i lighed med det infinitte, fetichisme og lignende. Tværtimod forstår man i dag årsager som meget forskellige og komplekse størrelser i lighed med Lakoffs og Johnsons forskellige årsagslogikker. Tiden er måske her ved begyndelsen af det 21. århundrede igen moden til de store oprindelsesteorier. Derfor bør vi ophæve tabuiseringen af Max Müller og de andre ‘oprindelige’ oprindelsesteoretikere og se på dem i et nyt lys. Og når vi begejstret kaster os over nye ideer, så er det godt at vide, at det, der bliver tænkt i dag, også kunne være tænkt i går.

\author{
Litteratur \\ BLACKMORE, SUSAN \\ 1999 The Meme Machine, Oxford. \\ FAUCONNIER, GILLES \& MARK TURNER \\ 1996 "Blending as a Central Process of Grammar” i A.E. Goldberg, ed., Conceptual Structure, \\ Discourse and Language, Stanford, 113-130. \\ 1998 “Conceptual Integration Networks”, Cognitive Science, 22 (2), 133-187. \\ FRANK, LONE \\ 1999 Weekendavisens kulturtillag, 9. dec., s. 4. \\ JORDAN, LOUIS, H. \\ 1905 Comparative Religion. Its Genesis and Growth, Edinburgh. \\ LAKOFF, GEORGE \& MARK JOHNSON \\ 1999 Philosophy in the Flesh:The Embodied Mind and its Challenge to Western Thought, New \\ York. \\ MALEFIJT, A. DE WAAL \\ 1968 Religion and Culture. An Introduction to Anthropology of Religion, New York. \\ Masuzawa, TomoKo \\ 1993 In Search of Dreamtime. The Quest for the Origin of Religion, Chicago.
}


MÜlLER, F. MAX

1878 Lectures on the Origin and Growth of Religion, London.

1881 "Comparative Mythology" i Selected Essays on Language, Mythology and Religion, London, 299-451.

NAYLOR, LARRY L.

1996 Evolution and Change, Westport.

SHARPE, ERIC J.

1975 Comparative Religion. A History, Bristol.

SøRENSEN, J. PODEMANN

1997 "Religionshistorie: Fagets tradition og perspektiv" kap. I.1 og "Epilog: Den store religions-generators genkomst” kap. I.6 i M. Rothstein, J. Podemann Sørensen og M. Warburg, eds., Humanistisk religionsforskning. En indføring i religionshistorie \& religionssociologi, København, 31-39; 124-128.

TURNER, MARK

1996 The Literary Mind. The Origins of Thought and Language, New York and Oxford.

\section{Summary}

This article is a rereading of Friedrich Max Müller's theory of the origin and growth of religion and mythology in the light of modern cognitive theories. The intention of this research is to draw attention to Max Müller's linguistic and cognitive hypothesis of mythology and religion and compare it to modern cognitive theories presented by Mark Turner, Gilles Fauconnier, George Lakoff and Mark Johnson. In the theory of Max Müller, notions such as 'myth being a disease of language' and 'man's propensity to religion' originate from a certain 'mental faculty', which reveals an ontologically distinct definition of religion. According to Max Müller, myth is the result of the defective attempt of early language to classify the surrounding world of man. These theories, which have been considered idiosyncratic and useless, appear more plausible in the light of current cognitive linguistics, and Max Müller's intuitions are viewed in the light of these recent theories.

Anita Maria Leopold

Ph.d.-stipendiat, cand.phil. Institut for Religionsvidenskab Aarhus Universitet 